\title{
The Frequency of Y Alu Polymorphism (YAP) Indel in the Minangkabau Malays in Peninsular Malaysia
}

\author{
Wan Nurhayati Wan Hanafi ${ }^{1}$, Muhd Shah Jehan Abd Razak ${ }^{1}$, Azzura Abdullah ${ }^{1}$, Nor Hazwani Ghani ${ }^{2}$, Nur \\ Azimah Osman ${ }^{2}$ and Farida Zuraina Mohd Yusuf ${ }^{1}$ \\ 1. Faculty of Applied Sciences, Universiti Teknologi MARA (UiTM), Shah Alam, Selangor 40450, Malaysia \\ 2. Faculty of Applied Sciences, Universiti Teknologi MARA (UiTM) Cawangan Negeri Sembilan, Kuala Pilah 72000, Malaysia
}

Received: August 14, 2014 / Accepted: September 30, 2014 / Published: September 30, 2014.

\begin{abstract}
Background: Minangkabau Malays (Melayu Minangkabau) is one of the Malay sub ethnic groups in Peninsular Malaysia. During the late 17th and early 18th centuries, migration of the Minangs from West Sumatra to the state of Negeri Sembilan Darul Khusus in Peninsular Malaysia took place and their descendants now form the main sub ethnic group in this state. The genetic polymorphisms of Y chromosome at DYS 287 locus were analyzed in Minangkabau Malays. Methods: A total of 41 buccal cells from healthy unrelated individual's males from Minangkabau Malays were typed for the DYS 287. The PCR products were separated on $2 \%(\mathrm{w} / \mathrm{v})$ agarose gel followed by visualization under UV light. Results: Three out of 41 samples $(7.32 \%)$ showed insertion $(\mathrm{YAP}+)$ polymorphism, while the rest of the samples (92.68\%) showed deletion (YAP-) polymorphism. This is the first report concerning the YAP in Malay population at Peninsular Malysia. Conclusion: The vAluable data obtained in this study will contribute to fill in the gap in the knowledge of YAP distribution in Malaysian population and will allow continuous interpretation of the evolution of YAP.
\end{abstract}

Key words: Y Alu insertion polymorphism (YAP), DYS 287, FTA, PCR, Minangkabau Malays.

\section{Introduction}

The human Y chromosome is a useful marker for studies of human population genetic and has been recognized [1-3]. The non-recombining portion of human $\mathrm{Y}$ chromosomes has special features where it is a single haploid and involve father to son transmission only. As a consequence, the DNA sequence on the Y chromosome preserves a unique record of mutational events that occurred in previous generations. Therefore, polymorphisms in this region have thus been proposed as tools for investigated male-specific gene flow and for reconstructing paternal history [4].

One of the most useful and widely studied is Y-linked polymorphisms or another name is Y Alu Polymorphism (YAP) element. YAP element (DYS

Corresponding author: Wan Nurhayati Wan Hanafi, M.Sc., research field: population genetics. E-mail: wannurhayati@salam.uitm.edu.my.
287 locus) is referred to the $A l u$ insertion ( $300 \mathrm{bp})$ that is present at a specific site on the long arm of the Y chromosome, Yq11 [5]. This element is stable and originated almost 65 years ago as a component in human DNA [6]. This type of marker has been shown to be vAluable for human population studies.

The people of Minangkabau or Minang make up majority of the population Negeri Sembilan Darul Khusus in Peninsular Malaysia and descendents came over from West Sumatera Province with the capital city of Padang [7]. The Minangkabau are known for the world's largest matrilineal social system, in which properties such as houses and land are inherited through female lineage. The Minangkabau have a history migrating to oversea such as Peninsular Malay during the late 17 th century and 18th century ago. They migrated from West Sumatera to the state of Negeri Sembilan Darul Khusus, especially in Naning, Sg. Ujong and Rembau after the fall of the Malacca 
Sultanate [8]. Nowadays Minangkabau features are still visible in traditional architecture and the dialect of Malay spoken in Negeri Sembilan.

This study was conducted on the insertion and deletion of the DYS 287 element in Minangkabau Malays in Peninsular Malaysia. There is still no research carried out in Peninsular Malaysia involving Malay sub-ethnic group especially in Minangkabau Malays as inferred from DYS 287 YAP. Recent study only focused on Bidayuh ethnics of Sarawak population which was conducted by [9] and also research done by [10] where the study focused on Kadazan-Dusun population from East Malaysia. Through this study, it shows that Bidayuh and Kadazan-Dusun show a small percentage of DYS 287 YAP insertion.

\section{Materials and Methods}

\subsection{Subpopulation Samples}

Ethical approval and written permission from each volunteer was obtained from the Research Ethics Committee, UiTM Shah Alam. Buccal cells were collected from 41 healthy volunteers, from non-related individuals and randomly selected for this study. The Minagkabau Malays was recruited from Kampung Gagu, Jelebu and Kampung Daching, Beranang from state of Negeri Sembilan Darul Khusus (Fig. 1).

The volunteers were interviewed to ensure their family history and their family must at least from three generations were selected (Fig. 2). Those with unknown family history, mixed marriages and consanguineous and marriage were excluded from this

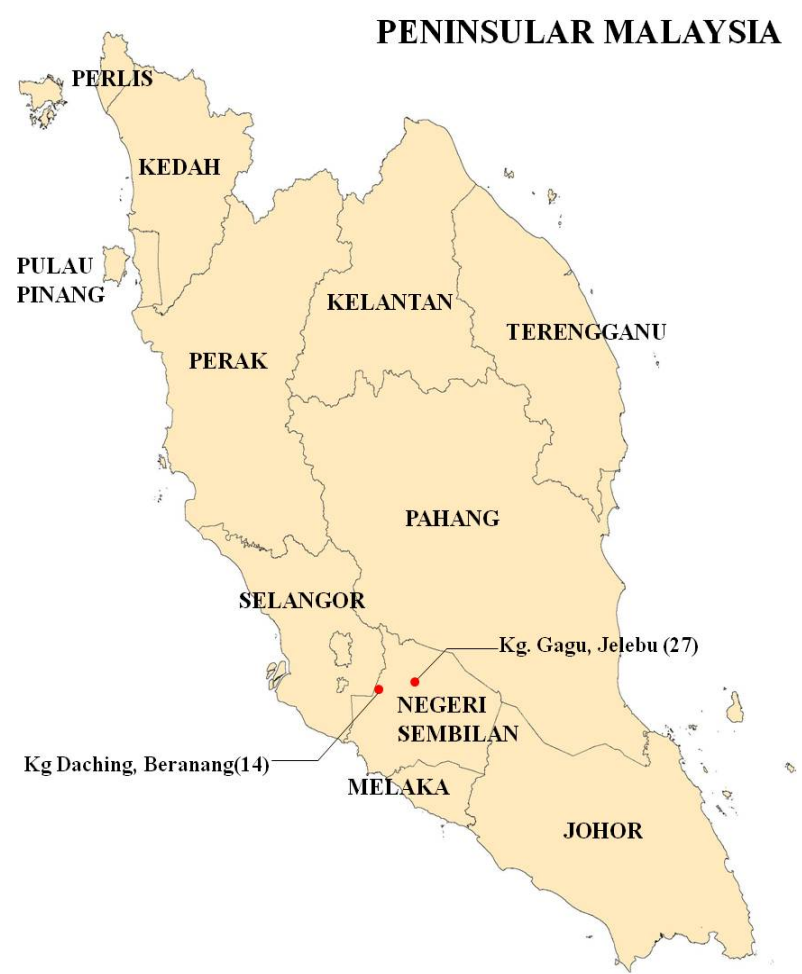

Fig. 1 Map of the geographical distribution of Minangkabau Malays individual.

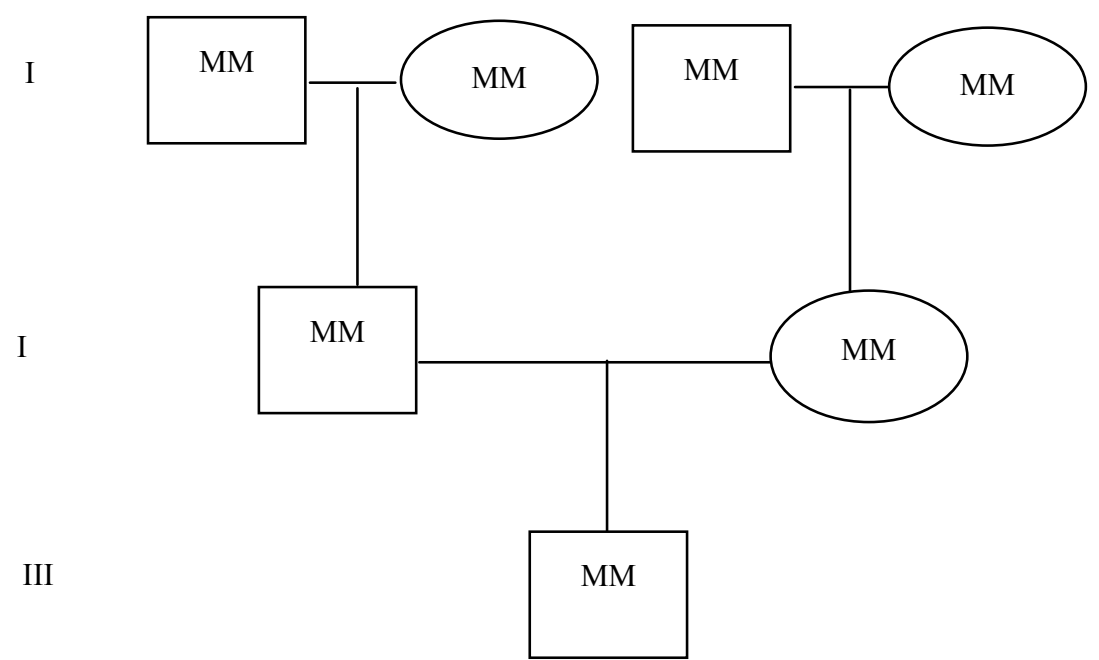

Fig. 2 A pedigree charts for ethnicity of an example of male representative through inclusion factor of three generation pure of Minangkabau Malays (MM) sub-ethnic groups. Squares designate males and circles represent females. Parents are connected by a horizontal line, and vertical lines lead to their offspring. 
study. Before donating a sample, each volunteer read and signed the consent form if they are part of this study. In favor of precise data acquisition, each volunteer must filled out the questionnaire, which asks detail regarding information on place of birth, ancestry of parents and grandparents and also current addresses.

The nationalities of each volunteer were defined by the Malaysian Identity Card (MyCard) as registered with National Registration Department. Volunteers were photographed with digital camera in front of the volunteer. All of the photographs were stored as JPEG files.

\subsection{Samples Collection}

Sample collection began with vigorously swabbing Sterile Foam Tipped Applicator (WHATMAN, Germany) inside a volunteer's mouth and rub side by side on the inside cheek for about one minute. The foam tip was transferred to FTA card (WHATMAN, Germany) and the color of FTA card changed from pink to white which indicated the presence of samples. FTA cards with whole buccal cell deposits were dried and stored at room temperature. The FTA cards were ready for further used.

\subsection{Washing FTA Cards}

A $2 \mathrm{~mm}(1 / 8 \mathrm{inch})$ disc the desire sample spot was punched out by using the $2.00 \mathrm{~mm}$ Harris Micro-Punch $^{\circledR}$ Tool (WHATMAN, Germany). The sample disc was place into the PCR tube. Add $200 \mu \mathrm{L}$ of FTA Purification Reagent (WHATMAN, UK) to each PCR tube and incubate for $5 \mathrm{~min}$ at room temperature. Next, all spent FTA purification was removed and discarded using a pipette. After that, the PCR tube was added with $200 \mu \mathrm{L}$ of TE (10 mM Tris, $0.1 \mathrm{mM}$ EDTA) buffer and incubated again for $5 \mathrm{~min}$ at room temperature. All TE buffer spent was removed and discarded using a pipette. Finally, the FTA disc was allowed to dry at room temperature for about one hour and the FTA card disc was ready for PCR amplification.

\subsection{PCR Amplification}

A complete list of the specific oligonucleotide primers are shown in Table 1. PCR was performed in the total volume of $25-\mu \mathrm{L}$ reaction which contain 2.0 mm disk Whatman ${ }^{\circledR}$ FTA card, $2.0 \mu \mathrm{L} \mathrm{MgCl}_{2}$ (Solis Biodyne, Estonia), $0.08 \mathrm{mM}$ dNTPs (Solis Biodyne, Estonia), $10 \times$ Reaction Buffer BD (Solis Biodyne, Estonia), $10 \mathrm{mM}$ oligonucleotide primer (AITBIOTECH PTE LTD, Singapore) one unit of Taq DNA Polymerase (Solis Biodyne, Estonia) and double distilled water. The PCR cycling conditions were carried out on Thermal cycler machine (Cleaver).

Each sample was subjected to an initial denaturation of $1 \mathrm{~min}$ at $94{ }^{\circ} \mathrm{C}$ followed by 35 amplification cycles of denaturation at $94{ }^{\circ} \mathrm{C}$ for $15 \mathrm{~s}$, annealing temperature for $30 \mathrm{~s}$, and followed by extension at $72{ }^{\circ} \mathrm{C}$ for $1 \mathrm{~min}$. After the final extension at $72{ }^{\circ} \mathrm{C}$ for $5 \mathrm{~min}$, the samples were kept at $4{ }^{\circ} \mathrm{C}$ until the end of electrophoresis set.

An amount of $8 \mu \mathrm{L}$ DNA was electrophoresed on $2 \%$ agarose gel containing $1.3 \mu \mathrm{L}$ Gold View ${ }^{\mathrm{TM}}$ Nucleic Acid Stain (Lonza, USA) at $100 \mathrm{~V}$ for about 70 min. PCR product was directly visualized using Gel Documentation System according to the manufacturer's instruction and molecular weight was determined using 100 bp DNA ladder (Solis BioDyne, Estonia).

\section{Results and Analysis}

Fig. 3 illustrated the photograph of $2 \%$ agarose gel

Table 1 Primer sets for PCR amplification of DYS 287 locus.

\begin{tabular}{llll}
\hline Name & Sequence (5'-3') & Expected Product Size (bp) & Adapted From \\
DYS 287 For & CA,GG,GG,AA,GA,TA,AA,GA,AA,TA & YAP+ 455 & {$[5]$} \\
DYS 287 Rev & AC,TG,CT,AA,AA,GG.GG.AT,GG,AT & YAP- 150 & {$[50$} \\
\hline
\end{tabular}


containing the PCR product YAP- of Minangkabau Malays while Fig. 4 illustrated the photograph of $2 \%$ agarose gel containing the PCR product YAP+ of Minangkabau Malays. The result was successfully amplified as a $150 \mathrm{bp}$ for YAP deletion and $450 \mathrm{bp}$ for YAP insertion.
The presence of positive control band was used to determine whether the PCR had succeeded meanwhile the absence of a negative control band indicated that the PCR is free from contamination. DYS 287 controls used for PCR amplification are female's sample and it showed no amplification of DYS $287 \mathrm{Y}$

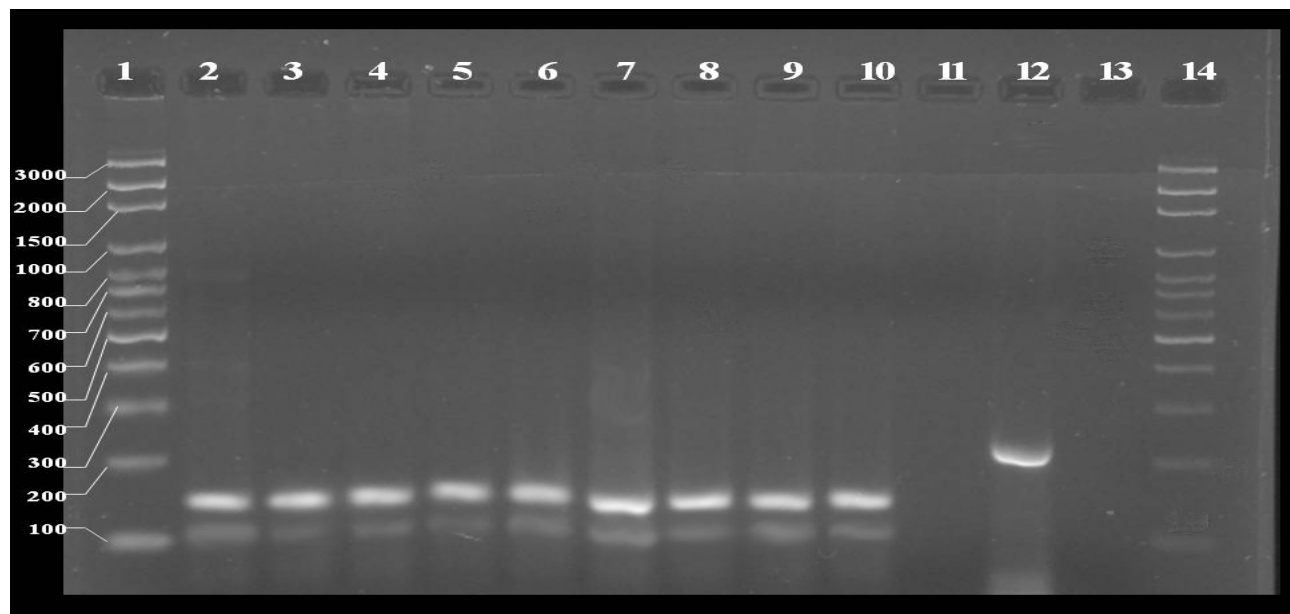

Fig. 3 Photograph of a $2 \%$ agarose gel containing the PCR products of Minangkabau Malays YAP-, negative control, positive control and female sample.

Lane from extremely left:

Lane 1: 100 bp DNA ladder

Lane 2: Minangkabau Malays 4

Lane 3: Minangkabau Malays 7

Lane 4: Minangkabau Malays 19

Lane 5: Minangkabau Malays 24

Lane 6: Minangkabau Malays 25

Lane 7: Minangkabau Malays 27
Lane 8: Minangkabau Malays 31

Lane 9: Minangkabau Malays 30

Lane 10: Minangkabau Malays 33

Lane 11: PCR negative control

Lane 12: PCR positive control

Lane 13: DYS 287 control

Lane 14: 100 bp DNA ladder

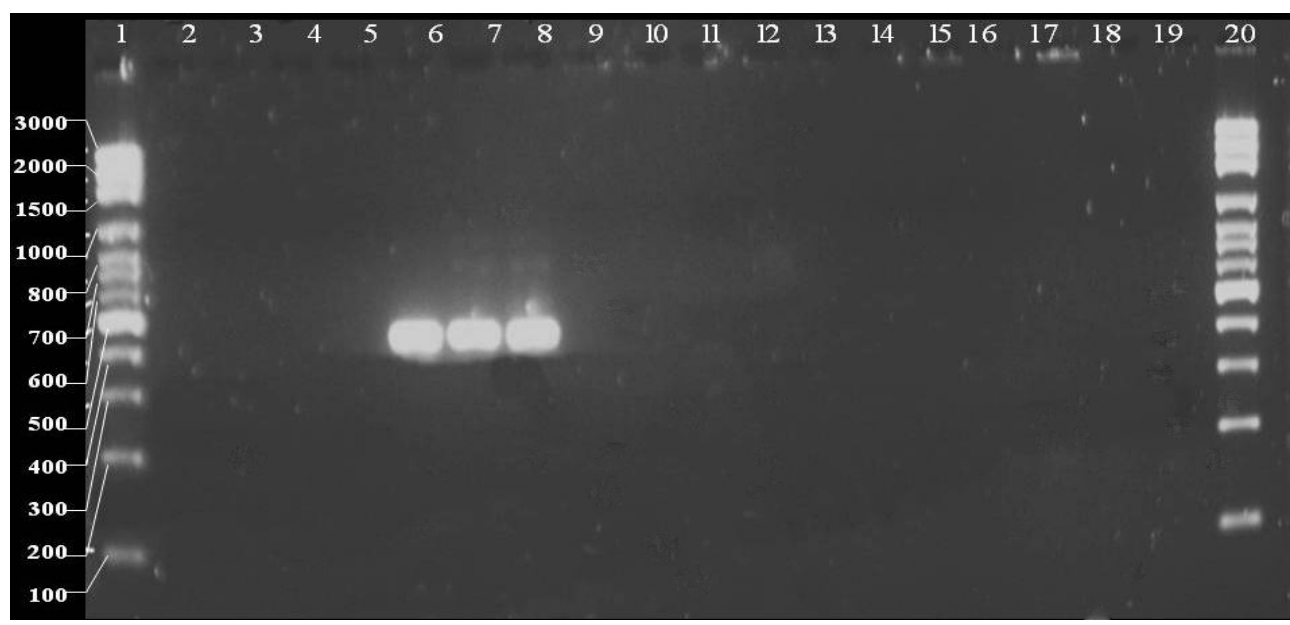

Fig. 4 Photograph of a $2 \%$ agarose gel containing the PCR products YAP+ of Minangkabau Malays.

Lane from extremely left:

Lane 1: 100 bp DNA ladder

Lane 2-5: No PCR product amplified

Lane 6: Minangkabau Malays 14
Lane 7: Minangkabau Malays 15

Lane 8: Minangkabau Malays 16

Lane 9-19: No PCR product amplified

Lane 20: 100 bp DNA ladder 
Table 2 Allele frequency distribution DYS 287 minagkabau Malays.

\begin{tabular}{llllll}
\hline Sub Ethnic Group & State & District & Total Samples & Yap + & Yap+frequencies (\%) \\
\hline \multirow{2}{*}{ Minangkabau } & Negeri & Jelebu & 27 & 0 & 0.0 \\
& Sembilan & Seremban & 14 & 3 & 7.3 \\
\hline
\end{tabular}

Alu element. It stated that the Y chromosome does not exist in female genome because it is a single haploid entity that passed from father to son only [11]. The allele frequencies distribution of the DYS 287 is reported in Table 2.

This study has shown that the Minangkabau Malay population lacks of YAP element and only $7.3 \%$ of subjects are having YAP+. Out of 41 subjects, $92.7 \%$ are having YAP-. This means their father did not inherit DYS 287 Y Alu polymorphisms from their common ancestor because Alu insertion polymorphism is identical by descent [12].

\section{Discussion}

A broad study of YAP insertion and deletion polymorphism in African, Europe, Asian and Oceania populations was carried out by [5]. The frequency YAP insertion polymorphism (YAP+) was significantly appeared at high frequency in African, Japan and Tibetans populations followed by the Western Eurasians populations and at low frequency in some Asian, and Oceania populations [5, 13, 14].

Recent study on YAP element among Ahmadiyya Muslim from Qadian, district of Punjab, Pakistan appeared no presence of YAP+ [15] and also research done by [16] where the study focused on polymorphism of Y chromosome at YAP locus among 25 ethnics groups in Yunnan China showed Primi, Tibetan, Naxi and Naxi (Mosuo) has the highest $\mathrm{YAP}+$ frequency.

In Southeast Asians, studies conducted by [13], could not find the frequency of $\mathrm{YAP}+$ in any populations (108 Filipinos, 42 Indonesians, and 74 Vietnamese) except in one Thai male sample. Previous study done by [17] also did not find among any of the Southeast Asians populations (3 Cambodian, 7 Laotian, 12 Philippine, 1 Thai and 3
Vietnamese).

Until now, there is yet to have any research carried out in Southeast Asians population involving ethnic group except Malaysia. In the case of DYS 287 among Malaysian population, research has been done by [9] in Kadazan-Dusun ethnic of Sabah population and recently, a local study conducted by [10] in Bidayuh ethnic of Sarawak population. Results obtained show a small percentage presence of YAP+ only $14.4 \%$ in Bidayuh and $2 \%$ in Kadazan-Dusun.

The results obtained in this study on Minangkabau Malay subjects is supported by previous studies [5] and [15] which conclude that most among Asian populations lack the YAP+ with the exceptions of the Japanese and Tibetan populations. At this moment, it is not clearly defined why the YAP element has this characteristics distribution high around Africa, Central Asia and East Asia.

\section{Conclusions}

Further studies examining more Malay sub-ethnic groups will provide a better understanding of DYS $287 \mathrm{Y}$ Alu polymorphisms pattern in Peninsular Malaysia.

\section{Acknowledgments}

This study was supported by Excellent Fund (RIF) granted to Universiti Teknologi MARA (UiTM) 600-RMI/DANA 5/3/RIF (393/2012).

\section{References}

[1] Ge, J., Budowle, B., Planz, J. V., Eisenberg, A. J., Ballantyne, J., and Ranajit, C. 2010. "US Forensic Y-chromosome Short Tandem Repeats Database. Elseviar." Elseviar 12: 289-295.

[2] Nadia, A. Z., Maria, P., Vincenza, B., Viola, G., Mohammed, A. H., Baharak, H. K., Anna, O., Antonio, T., Augusta, S. S-B., and Ornella, S. 2011. "In Search of the Genetic Footprints of Sumerians: A Survey of Y 
Chromosome and mtDNA Variation in the Marsh Arabs of Iraq." BMC Evolutionary, Biology 11 (288): 1-46.

[3] Primorac, D., Marjanović, D., Rudan, P., Villems, R., and Underhill, P. A. 2011. "Croatian Genetic Heritage: Y-chromosome Story.” Croatian Medic. Journal 52 (3): 225-234.

[4] Mizuno, N., Kitayama, T., Fujii, K., Nakhara, H., Yoshida, K., Kazumasa, S., Naoto, Y., Minoru, N., and Kentaro, K. 2011. "A Forensic Method for the Simultaneous Analysis of Biallelic Markers Identifying Y Chromosome Haplogroups Inferred as Having Originated in Asia and the Japanese Archipelago." Forensic Science International Genetics 4: 73-79.

[5] Hammer, M. F. 1994. "A Recent Insertion of an Alu Element on the Y Chromosome is a Useful Marker for Human Population Studies." Molecular Biology Evolution 11 (5): 749-761.

[6] Tripathi, M., Cauhan, U. K., Tripathi, P., and Agrawal, S. 2008. "Role of Alu Element in Detecting Population Diversity," International Journal Human Genetic 8 (1 \& 2): 61-74.

[7] Azima, M. A. 2009. "Masalah Dan Cabaran Tanah Adat Minang di Dunia Melayu Dan Indonesia, Malaysian." Journal of Society and Space 5 (1): 69-78.

[8] Haji-Tajuddin, H. H., Suhaiza, I., and Robiah. A. 2009. Malaysia Negara Kita. Kuala Lumpur: MDC Publisher.

[9] Vasudevan, R., Fatihah, C. P. N., and Patimah, I. 2011. "Analysis of Three Polymorphisms in Bidayuh Ethnic of Sarawak Populatio." African Journal of Biotecnology 10 (22): 4544-4549.

[10] Lian, L. H., and Koh, C. L. 2006. "Genetic Polymorphism of Two Chromosome Markers (DYS287 and DYS385) in Kadazan-Dusun Population Samples from East Malaysia." Malays Applied Biology 35 (1): $37-42$.

[11] Tilford, C. A., Kuroda'Kawaguchi, T., Skaletsky, H., Rozen, S., Brown, L. G., Michael, R., John, D. M., Kristine, W., Mandeep, S., Tamara, A. K., Robert, H. W., and David, C. P. 2011. "A Physical Map of the Human Y Chromosome." Nature 409: 943-945.

[12] Naris, P., Elma, S., Belma, K., Lejla, K-P., Lejla, L., Una, T., and Rifat, H. 2013. "Polymorphic Alu Insertions in Human Populations of Bosnia and Herzegovina." Annals of Human Biology 40 (2): 181-185.

[13] Spurdle, A., Hammer, M. F., and Jenkins, T. 1994. "The Y Alu Polymorphisms in Southern Asia Populations, and its Relationship to Other Y specific polymorphisms." American Journal of Human Genetics 54: 319-330.

[14] Hammer, H., and Horai, S. 1995. "Y Chromosomal DNA Variation and the Peopling of Japan." American Journal Human Genetics 56: 951-962.

[15] Badaruddoza, A., Bhanwer, J. S., Rambani, M., Singh, R., Matharoo, K., and Bamezai, R. N. K. 2008. "Study of YAP Element among and Endogamous Human Isolate in Punjab." International Journal Human Genetic 8 (3): 269-271.

[16] Honng, S., Yongli, D., Weixiang, L., Jie, Y., Kaiyuan, L., Ruiguang, Z., and Chunjie, X. 2003. "The Geographical Polymorphism of Y Chromosome at YAP Locus among 25 Ethnic Groups in Yunnan, China." Science in China: 46 (2): 135-140.

[17] Bravi, C. M., Bailliet, G., Martínez-Marignac, V. L., and Bianchi, N. O. 2001. "Tracing the Origin and Geographic Distribution of an Ancestral Form of the Modern Human Y chromosome." Revista Chilena de Historia Natural 74: 139-149. 